\title{
Legislation and the Stress of Environmental Problems
}

\author{
Eloise Scotford ${ }^{*}$
}

\begin{abstract}
For lawyers and legal scholars, legislation seems a known quantity - a relatively permanent, public expression of democratic processes in parliamentary democracies and of the rule of law. This 'knowable' character can however be misleading, particularly in the field of environmental law. This article examines why research into environmental legislation is challenging but critically important. A short history of UK environmental law provides salient examples of political stress and highly complex, unsettled, even unknowable, environmental legislation. Collective environmental problems demand legislative responses in shaping individual behaviours and guiding social policies-but knowing how to craft these responses and how to evaluate the resulting legislation is often uncharted legal territory. Navigating that legislative terrain is a vital task for legal scholars and practitioners, particularly to investigate the serious legal problems that can arise from its construction, including poor legibility, legal fragmentation, and concerns about compatibility with the rule of law.
\end{abstract}

\section{Introduction}

This article examines legislation that relates to environmental problems. Analysing environmental legislation-or legislation at all-has not conventionally been a fashionable topic in Anglo-American legal scholarship. Legislation has often been seen as 'dull', ' as anathema to legal tradition, ${ }^{2}$ or, slightly more positively, as the 'Cinderella' of legal

Professor of Environmental Law, Faculty of Laws, University College London. Thank you to Liz Fisher and the anonymous referees for thoughtful and helpful comments on an earlier draft of this paper, and to Paul Mitchell for his great patience in editing this article. All errors remain my own.

1 PJ Fitzgerald, 'Are Statutes Fit for Academic Treatment' (1971) 3 Journal of the Society of Public Teachers of Law 142.

2 This attitude is deep rooted in the English common law. Coke and Blackstone advocated the purity and rationality of the common law, unpolluted by statute, see eg Harbert's Case (1584) 3 Co Rep 11b, 13b. This scepticism goes back even further and 
scholarship. ${ }^{3}$ However, in environmental law, legislation is the backbone of much of our legal field. ${ }^{4}$ This article examines the complex and uncharted characteristics of environmental legislation, focusing on UK environmental legislation, and the important but challenging role of legal researchers in appraising this body of law. It also argues more fundamentally for the importance of legislation, as a part of environmental law and as an area for legal research.

The article is framed in three parts. First, it considers reasons for the reluctance to embrace legislation as a topic for legal inquiry. These reasons are historical, philosophical, and pragmatic. It highlights the longstanding skepticism of social and economic legislation as being particularly capricious, and an inferior source of law, particularly in contrast to the pure and rational common law. This inferiority was partly due to the tendency of this kind of law to respond to the 'stress of circumstances'. ${ }^{5}$ Against or despite these reasons, the second part of the article considers the virtues of legislation, and the reasons for the prominence of this form of law in environmental law. Collective, socio-politically contested and dynamic problems are well suited to lawmaking by legislation. And there are many instances of environmental law development where the stress of circumstances has driven legislative change. Whether it be a rapidly changing climate, developing knowledge about environmental threats, or major constitutional change (such as UK devolution, and the UK's departure from the European Union), circumstances have demanded a policy and legal response in relation to environmental problems that legislation is well suited to provide. Whilst legislation can be compromised by politics and time pressures, ${ }^{6}$ often leading to valid concerns over legislative quality, this is nonetheless socially vital law that requires interpretation, evaluation, and re-evaluation over time.

can be seen in Roman law: R Zimmermann, 'Statuta Sunt Stricte Interpretanda? Statutes and The Common Law: A Continental Perspective' (1997) 56(2) CLJ 315.

3 B Hepple, 'The Renewal of the Liberal Law Degree' (1996) 55(3) CLJ 470, 481. In 2019-20, legislation had a major moment in UK law - Brexit providing this Cinderella's moment at the ball, as the UK and its devolved administrations sought to adapt their statute books to ensure continuity of laws and institutions as the United Kingdom left the European Union (see Section 4(c)).

${ }^{4}$ E Fisher, Environmental Law: A Very Short Introduction (OUP 2018) 23.

5 AV Dicey, Lectures on the Relation between Law and Public Opinion in England During the Nineteenth Century (Macmillan 1905) 300-1.

${ }^{6}$ R Lazarus, 'Super Wicked Problems and Climate Change: Restraining the Present to Liberate the Future' (2009) 94 Cornell Law Review 1153, 1179-1187 (outlining reasons why climate change is 'environmental lawmaking's worst nightmare' in the US context). 
The final part of the article considers the scholarly and practical challenge in undertaking this evaluation. The challenge is not to disparage or ignore legislation but to make sense of it through robust scholarly methods. ${ }^{7}$ For much environmental legislation, this task is methodologically demanding, since new legal concepts, obligations and amendments are frequent, and policy direction and outcomes are explicitly embedded in much legislative drafting. For lawyers and legal scholars, these conditions are not just complex, they can seem unknowable and even anathema to conceptions of what law should be. This part demonstrates these challenges by examining UK environmental legislation in two historical episodes - examining the statute book of UK environmental legislation as it developed up until its major reform to accommodate the UK's departure from the European Union; and statutory reform for a functioning body of domestic UK environmental legislation in the wake of Brexit. These two episodic examples highlight the devilish complexity of much environmental legislation (the 'purity' of the common law has no place in this body of law), with implications for the rule of law and environmental protection, and reinforcing the importance of robust legal analysis and well-framed scholarly inquiry in making sense of this body of (ever changing) law.

A definition and a caveat are worth making at the outset. By 'legislation', this article refers to enactments formally passed by properly constituted lawmaking assemblies (legislatures). As for the article's scope, whilst it is focused on UK environmental law, it is not a comprehensive assessment of all UK environmental legislation. It is focused mainly on legislation that applies to England or the UK as a whole, with examples drawn from the devolved administrations where these are illuminative. Its analysis is based on the law as it stands on 28 September 2021, at which time significant parts of UK environmental legislation remained in a state of flux in light of the complex and uncertain political and legal processes for the UK's departure from the European Union. ${ }^{8}$ The

7 Fitzgerald (n 1). This challenge has been recognized by academics for nearly 100 years: HF Stone, 'The Common Law in the United States' (1936) 50 Harv L Rev 4, 12 ('[Scholars'] role has been almost exclusively that of destructive critics, usually after the event, of the inadequacies of legislatures. There has been little disposition to look to our own shortcomings in failing, through adaptation of old skills and the development of new ones, to realize more nearly than we have the ideal of a unified system of judgemade and statute law...')

${ }^{8}$ The end of the 'transition period' on 31 December 2020 is a critical date on which structures of EU environmental law fall away, requiring replacement policy and governance structures to be established by UK legislation (both at Westminster and in the devolved parliaments). See Section 4 below. 
frustrating - and failed-attempt to finalise this article at a moment where UK environmental legislation had reached a newly settled phase with the introduction of new, generation-defining English Environment Act only reinforced the arguments of this article about the unsettled and dynamic nature of much environmental legislation.

\section{The Unpopularity of Legislation}

Legal commentators and scholars have long maintained skepticism about legislation as a form of law and subject of inquiry. This has led to a paucity of scholarly analysis of legislation, ${ }^{10}$ and presents an intellectual handicap for environmental law scholars, when much of our subject involves statutory regimes. Legislation has not been a popular topic for legal research for at least three reasons.

One reason is the deep-seated, historical animosity towards legislation from juridical and academic figures who have been fiercely defensive of the common law and suspicious of legislatures. At one ideological extreme, Friedrich von Hayek's vision of law denied that legislation was in fact law (not 'lawyer's law'). ${ }^{11}$ He resisted the role of socializing legislation, involving measures that must be executed by government or imposed on individuals, as opposed to rules of 'just conduct' that supported the existing order of things, allowing greater individual liberty. For Hayek, legislation implied a managerial vision of society, undermining individual freedom. Promoting this kind of

9 Thus Section 4 explores the UK/English 'Environment Bill' in some detail. The clause numberings of this Bill were volatile at the time of writing this article, and footnote references are to the clause numbers in the House of Lords version of the Bill as it was preparing for its third reading in the Lords: HL Bill 53 (as amended on Report). These numberings are likely to change in the final Act, and I beg the reader's patience to deduce any updated section numbers from the context of the discussion in the article.

${ }^{10}$ This is not to say there is not excellent scholarship examining legislation (eg L Wintgens (ed), Legisprudence: A New Theoretical Approach to Legislation (Hart Publishing 2002); and the rich journal issues of the Statute Law Review and The Theory and Practice of Legislation), and examining the interaction of common law and statutes (eg PS Atiyah, 'Common Law and Statute Law' (1985) 48 MLR 1; M Lee, 'Safety, Regulation and Tort: Fault in Context' (2011) 74(4) MLR 555). Legal scholars who do pay attention to statute often bemoan the scant attention paid to legislation by legal philosophers: J Waldron, The Dignity of Legislation (CUP 1999) ch 1; N Duxbury, Elements of Legislation (Cambridge University Press 2013) 57.

${ }^{11}$ FA Hayek, Law, Legislation and Liberty (vol 1) (1973, reprinted 1998, Routledge) 67 and chs 3-6 generally. Notably Hayek was not a lawyer, rather approached legislation from the perspective of economics and philosophy. 
law facilitated 'the organization of a totalitarian order' ${ }^{12}$ Whilst there was a role for legislation, including in remedying injustices in the common law and responding to 'wholly new circumstances', this role was derivative and marginal. ${ }^{13}$

Another source of historical animosity to legislation was deep legal conservatism. This is partly a nostalgic view-in 1953, Lord Radcliffe referred to statute law as the 'ugly modern highway with its roaring traffic and its straight harsh lines' and the common law to 'by-ways that lead so pleasantly to park and manor house and old world cottages and the village green'. ${ }^{14}$ This image relates to a vein of legal thought maintaining that legislation is qualitatively inferior to the common law. In 1948, the VC of Oxford was 'sure that the Oxford Law School has been wise in excluding from its course those branches of the Law which depend on Statute and not on precedent'. ${ }^{15}$ As far back as 1584, Sir Edward Coke in Harbert's Case, dealing with a statute concerning the execution of debts, made clear that 'Judges and sages of the law have always expounded [or interpreted] general statutes according to the rule of the common law, which is built on the perfection of reason, and not according to any private and sudden conceit or opinion'. ${ }^{16}$ This view of common law reasoning being a more perfect or rational method of lawmaking has persisted as a reason for disparaging legislation. Sir Jack Beatson noted that it might even be a 'psychological' issue for some lawyers that statutes appear as an exception rather than a mainstream form of lawmaking. ${ }^{17}$

Against this, there have been opposing views historically, often radical political and legal theories supporting the role of legislatures, as seen in the Benthamite vision of the omnicompetent legislature. For Bentham, the common law was corrupt and subjective and should be codified; the term 'law' 'was invented ... to denote a general Command of Public

12 ibid 114.

13 ibid 88-90. This view traced through in judicial approaches to statutory construction that strictly limited incursions into common law doctrine by statutory provisions: Stone (n 7) 12-13 ('a curiously illogical chapter in the history of the common law'); Zimmermann (n 2) 318-319 (linking this restrictive approach to statutory interpretation to 'respectable-sounding considerations of constitutional theory').

${ }^{14}$ CJ Radcliffe, 'Law and the Democratic State', Presidential Address of the Right Hon Lord Radcliffe, President of the Holdsworth Club of the Faculty of Law in the University of Birmingham, 1954-

55 (Holdsworth Club of the University of Birmingham).

15 B Abel-Smith and R Stevens, Lawyers and the Courts (Heinemann Educational Books 1967) 163.

${ }^{16}$ (n 15) 41.

17 J Beatson, 'Does the Common Law Have a Future?' (1997) 56(2) CLJ 291, 301. 
Government'. ${ }^{18}$ A more practical vision of codifying the common law was supported by prominent $19^{\text {th }}$ century judges, such as Lord Westbury and Lord Cairns (who were deciding and struggling with significant common law cases on environmental pollution and harm at the time). ${ }^{19}$ In Lord Westbury's view, the common law and developing body of Victorian statute law would ideally have been reformulated into a digest to develop a more certain and coherent body of law. ${ }^{20}$

The view disparaging legislation is partly a relic of history, reflecting a time when legislative activity, and the regulatory state that fuels this, was much less or only emerging. Times have changed and the role of legislation has become increasingly significant as our welfare and administrative state has developed and expanded, markets and social interconnections have become more complex ('society [has grown] in size and sophistication'), ${ }^{21}$ knowledge of externalities better known, governments more empowered, and MPs and Parliament more professionalized (particularly with the role of Parliamentary Counsel). By the late $19^{\text {th }}$ century, legislation-and the administrative state it was constructing-was a 'growth industry'. ${ }^{22}$

However, the turn towards increasing amounts of social and economic legislation-such as environmental legislation or workplace protection laws-has remained controversial. In his 1905 Lectures on the Relation between Law and Public Opinion in England During the Nineteenth Century, A V Dicey spoke of the late $19^{\text {th }}$ century trend of 'legislation of collectivism', which was threatening to individualistic values and promoted socialistic ideas that are 'guided far less by the force of argument than by the stress of circumstances'. ${ }^{23}$ For Dicey, legislating for popular or urgent needs of collective social policy was rash and undermined individual rights and even happiness.

18 As cited in G Postema, Bentham and the Common Law Tradition (2nd edn, OUP 2019) 302. Hobbes also identified legislation as law on the command theory of law: $T$ Hobbes, Leviathan (1651).

19 St Helen's Smelting v Tipping (1865) 11 HL Cas 642; Rylands v Fletcher (1868) LR 3 HL 330.

${ }^{20}$ See R Cocks, 'Victorian Foundations?' in J Lowry and R Edmunds, Environmental Protection and the Common Law (Hart Publishing 2000) 21-23 and generally. Lord Westbury was one of several leading judges appointed to an 1866 Royal Commission 'to enquire into the expediency of a Digest of law, and the best means of accomplishing that object, and of otherwise exhibiting, in compendious and accessible form, the law as embodied in judicial decisions'.

${ }^{21}$ Postema (n 18) 302, explaining Bentham's view of why explicit general commands became needed to establish a 'centralised, systematic, and fully public structure of law'.

${ }^{22}$ Cocks (n 20) 19.

23 Dicey (n 5). 
Furthermore, legislation can be ossifying or paralyzing-setting general norms down in legislation comes at the cost of the flexible adaptability of the common law. ${ }^{24}$ Again, the purist rationality of the common law gripped philosophical thinking about the law. More recently and more ideologically, social and economic legislation is perceived by some as a threat to one version of the rule of law, if the rule of law is seen as a guarantee of basic substantive legal conditions that promote flourishing financial markets. ${ }^{25}$ This includes protection of property rights and protecting freedom of contract and other market-enabling norms, as guaranteed through common law doctrines of contract and property. Social legislation, like environmental legislation, is seen, by contrast, as the unjustified wielding of state power, creating a society of capricious rule by men (in power for a period of time), expanding state control over people's lives, rather than rule of 'law'. ${ }^{26}$

Beyond these reasons for hostility of lawyers towards legislation, another reason for neglecting legislation as an area of legal inquiry or controversy has been complacency, or perhaps slightly more positively, that we know what we are doing with legislation. Lawyers come out of law school feeling comfortable with statutes as a key part of the materials that lawyers use-we know how to read, interpret, apply legislation. Statutes are comfortingly static and solid, unless major reforms come along, and as legal academics and practitioners we often feel we should focus on ever changing case law to stay up to speed and see where interesting legal developments are occurring. ${ }^{27}$

A third reason for legislation's historical lack of popularity as an area of legal inquiry, which may still hamper research in this area, is the dullness factor. ${ }^{28}$ Lengthy, technical legislation is very dry-interpreting legislation has been described as intellectually exacting but

24 In the preface to Private International Law (1st edn, OUP 1935), Professor Cheshire said that one of the subject's virtues was that 'it has been only lightly touched by the paralysing hand of the Parliamentary draftsman'.

25 Eg RJ Barro, 'Determinants of Democracy' (1999) 107(S6) Journal of Political Economy S158.

${ }^{26}$ On this view, there is 'something dodgy' about legislation from a rule of law perspective when it extends beyond guaranteeing basic market freedoms: J Waldron, 'Legislation and the Rule of Law' (2007) 1(1) Legisprudence 91, 120.

${ }^{29}$ EL Rubin, 'Law and Legislation in the Administrative State' (1989) 89(3) Col L Rev 369, 369 ('The principal reason why we lack a theory of modern legislation that legal scholars have focused so heavily on the judiciary. They analyze the work of judges, they address themselves to judges, they use the same terminology as judges, and quite frequently, they even think like judges.')

${ }^{28}$ Fitzgerald (n 1) 144-15 (suggesting 6 reasons why cases are more interesting than statutes). 
spiritually sterilising. ${ }^{29}$ A P Herbert's 1935 satirical book on the common law-Uncommon Law-explained (via a cranky judge) that there are no 'references to fun' in statutes. ${ }^{30}$ However, reading and digesting statutes can be deeply interesting. Bringing legislation to life requires legal expertise, imagination, ${ }^{31}$ and a keen awareness of the sociopolitical context in which the legislation was both drafted and must be implemented. Legal academics (and practitioners) possess these qualities and so perceived or superficial dullness is not a good enough reason to avoid or disparage research into legislation. Quite the opposite, the devil is often in the detail, and in seeing what the detail adds up to.

\section{Why Legislation is Important}

This dismal and quite cynical picture of legislation is not the only way of looking at things. For democratic, political and constitutional reasons, there is much to value in legislation as an important and fundamental part of our system of law. This is particularly the case for environmental legislation, which is a vital response to collective environmental problems.

\section{A. The Virtues of Legislation}

Legislation is a fundamentally important part of our legal and political system. First and foremost, it is important for lawmaking reasonslegislatures provide a forum for navigating disagreements over policy issues and determining an accepted basis for 'action-in-concert' across society. ${ }^{32}$ They allow the investigation and testing of policy ideas through Parliamentary deliberation, consultation, expert advice, and ultimately general decisions of policy or principle to be made on the basis of voting and enactment. For Jeremy Waldon, it is not a simple theory of representative democracy that justifies such legislative

${ }^{29}$ Lord Evershed, 'The Judicial Process in England' in Essays in Jurisprudence from the Columbia Law Review

(1963) cited in Beatson (n 16) 299.

30 AP Herbert, Uncommon Law (Methuen 1935) ('people must not do things for fun').

${ }^{31}$ E Fisher, 'EU Environmental Law and Legal Imagination' in P Craig and G De Burca (eds), The Evolution of EU Law (3rd edn, OUP 2021).

$32 \mathrm{~J}$ Waldon, Law and Disagreement (OUP 1999) ch 5 ('A piece of legislation deserves respect because of the achievement it represents in the circumstances of politics: actionin-concert in the face of disagreement': 108). 
measures as law, ${ }^{33}$ but lawmaking through 'a process that related a legislative proposal to the complexity and multiplicity of persons, regions, relations, and circumstances, with which the proposed law would have to deal'. ${ }^{34}$ In the field of environmental law, this lawmaking function is particularly important, since environmental problems are infused with socio-political issues that require complex policy judgments to be made, involve diverse stakeholders and geographies, and often give rise to intense and ongoing political disagreement (such as the level of protection to be adopted in relation to water or air quality, and the behaviours to regulate in order to reach that standard). ${ }^{35}$ These are not the kinds of disagreements or issues that the common law is suited to addressing through bilateral adjudication, ${ }^{36}$ which is essentially concerned with vindication of individual rights. ${ }^{37}$ There is only so much the law of public nuisance can do for environmental protection, or private nuisance for that matter. ${ }^{38}$

Legislation is particularly important as a means for setting and updating social goals. In the face of social, economic, environmental and demographic change, or new knowledge about these aspects of society, the law needs to adjust and adapt. As Waldron eloquently puts it, 'That matters like these may need collective attention from time to time is not a cranky or anomalous position; it is not Bolshevik or socially destructive; it is the ordinary wisdom of human affairs. ${ }^{39}$ As noted above, ${ }^{40}$ even Hayek acknowledged that legislation is required to adapt the law to 'wholly new circumstances' but, in relation to environmental issues, this requirement is the norm rather than the exception. This political necessity may pose philosophical questions about the integrity of a legal

33 There are reasons to be skeptical about the democratic credentials of legislation on this basis: ibid 53 .

34 ibid 55. See also R Cormacain, 'Legislation, Legislative Drafting and the Rule of Law' (2017) 5(2) The Theory and Practice of Legislation 115.

35 Environmental regulation is driven by competing perspectives, values and, fundamentally, politics: Fisher, Lange and Scotford, Environmental Law: Text, Cases and Materials (2nd edn, OUP 2019) chs 2 and 12.

36 Even if some early common law cases might be seen as 'filling the gap' in environmental regulation: Cocks (n 20); B Pontin, Nuisance Law and Environmental Protection: An Analysis of the Enforcement of Injunctions (Lawtext Publishing Ltd 2013).

${ }^{37}$ R Dworkin, Law's Empire (Hart Publishing 1986).

38 Coventry v Lawrence [2014] UKSC 13; Cocks (n 20); cf M Lee, 'The Public Interest in Private Nuisance: Collectives and Communities in Tort' (2015) 74 Cambridge Law Journal 329.

39 Waldron, 'Legislation and the Rule of Law' (n 26) 121-2.

40 (n 13) and accompanying text. 
system, ${ }^{41}$ but it presents a vision of our legal and regulatory order in which legislation plays a major role. As the $19^{\text {th }}$ century jurist Henry Maine noted, in the face of rapid social and technological change, 'social necessities and social opinion are always more or less in advance of Law. . Law is stable; the societies of which we are speaking are progressive. The greater or less happiness of a people depends on the degree of promptitude with which the gulf is narrowed. ${ }^{, 42}$ In other words, legislation is vital for important social issues to be addressed through law in a timely way.

Legislation is also important for constitutional reasons-it establishes frameworks for the lawfulness of executive action and, as the 'epitome of lawmaking', embodies many aspects of the rule of law ideal (on many theoretical accounts of that concept). ${ }^{43}$ In principle, legislation is publicly available and accessible, the process of making legislation is transparent and highly formalised, ${ }^{44}$ legislation can establish rules that govern both individual and governmental action in advance. ${ }^{45}$ And for rule of law reasons, it is important that legislation in fact possesses these attributes.

In theory at least, through formal legislative processes that address policy disagreements and the predictability that legislation brings to the rules that govern us, legislation becomes a 'settled, solid, known' part of the legal landscape. And in settled times, in relation to knowable issues and well-known statutes, that is how legislation tends to operate. But environmental problems are not always knowable and the times are not always so settled, whether in the UK through the era of Brexit, or internationally in light of environmental crises (amongst other global challenges). These times, this disruption, ${ }^{46}$ particularly in the environmental context, show that legislation-drafting it, debating

${ }^{41}$ As Stone (n 7) noted in US context in the wake of industrialisation: 'Rapid social change, more than all else, puts to the test a legal system which seeks its inspiration and its guidance in a past which could make no adequate prophecy of the future.' (11) See also Cocks (n 20) 20.

${ }^{42}$ H Maine, Ancient Law (John Murray 1905) 24.

43 Waldron, 'Legislation and the Rule of Law' (n 26) 99.

44 According to Dicey, 'the commands of Parliament (consisting as it does of the Crown, the House of Lords, and the House of Commons) can be uttered only through the combined action of its three constituent parts, and must, therefore, always take the shape of formal and deliberate legislation.' (A V Dicey, Introduction to the Study of the Law of the Constitution (repr 8th edn Macmillan 1915, Liberty Classics 1982).

45 Satisfying key requirements of the rule of law: T Bingham, The Rule of Law (Penguin 2011).

${ }^{46}$ See also E Fisher, E Scotford and E Barritt, 'The Legally Disruptive Nature of Climate Change' (2017) 80(2) Modern Law Review 173. 
it, shaping it, agreeing it, understanding it - is a pressing topic for analysis and debate, which can give rise to fraught methodological and theoretical questions. That is, environmental legislation often provokes questions about how we analyse and understand legislative developments in a rigorous way, and how we think about the nature of law and how it should govern us.

\section{B. The Prominence of Legislation in Environmental Law}

Returning to Dicey, he was writing at a time when regulation of collective problems by the state through legislation was a relatively recent phenomenon in England. Through urbanization and industrialization, and their polluting byproducts, the case for regulating environmental problems had become pressing through the $19^{\text {th }}$ century, and a series of general environmental statutes began to be passed in England. These included a series of Public Health Acts (1848, 1858, 1875), the Alkali Act of 1863 (controlling certain forms of industrial pollution), and the Rivers Pollution Prevention Act 1876. Major statutes were also passed in the $20^{\text {th }}$ century, often in response to environmental crises, such as the Clean Air Act 1956, which brings us into the modern era of environmental legislation.

This potted story of legislative development is not unique to England or to the UK, and we see that legislation is the usual legal response to environmental problems in many parliamentary systems of government. ${ }^{47}$ This is because of the nature of environmental problems: they are collective (in both cause and impact-degradation of biodiversity is not due to a single individual's act and its remediation is addressed by a collective set of responses); they concern externalities to a variety of social and economic behaviours that humans unthinkingly (or thinkingly but carelessly) undertake, often for reasons of maximizing their own welfare; they are dynamic; and often beset with scientific uncertainty. ${ }^{48}$ Environmental problems can also be existential (climate change, or biodiversity loss) and implicate complex questions of social justice (consider house prices on highly polluted streets, or some of the countries being worst affected by climate change).

Addressing these kinds of problems through law rarely fits neatly into existing legal doctrines or categories and is not easily done through bilateral adjudicative disputes, as indicated above. ${ }^{49}$ Beyond common

${ }^{47}$ Fisher, Environmental Law: A Very Short Introduction (n 4) 23-26.

${ }^{48}$ Fisher, Lange and Scotford (n 35) ch 2.

49 (n 36) and accompanying text. See also Fisher, Scotford and Barritt (n 46). 
law approaches, promoting individual freedom of action, reliance on markets, or self-help in thinking about norms for environmental protection ('buy a house away from that terrible pollution') is to ignore or misunderstand the nature of environmental problems. If a society places political value on addressing environmental problems, this typically requires legislation to decide on concerted and collective action relating to complex environmental problems. ${ }^{50}$ It also usually requires legislation that establishes administrative architectures to allow us to understand and monitor scientifically complex environmental problems, as much as to regulate behaviour to ameliorate, remedy or prevent them. Even with economic instruments or more consensual approaches to dealing with environmental problems, the state has a key role in establishing and implementing environmental regimes. ${ }^{51}$

Thus, in the UK today, we have extensive legislative regimes that relate to air quality control, ${ }^{52}$ environmental permitting, ${ }^{53}$ greenhouse gas (GHG) emissions trading, ${ }^{54}$ waste regulation, ${ }^{55}$ biodiversity and wildlife protection, ${ }^{56}$ climate change regulation, ${ }^{57}$ water pollution and water standards, ${ }^{58}$ town and country planning, ${ }^{59}$ environmental impact assessment, ${ }^{60}$

50 Waldron, Law and Disagreement (n 32) 101 ('Our respect for legislation is in part the tribute we should pay to the achievement of concerted, co-operative, co-ordinated, or collective action in the circumstances of modern life.')

${ }^{51}$ Fisher, Lange and Scotford (n 35) 256-9.

52 Environment Act 1995, pt IV; The Air Quality Standards Regulations 2010 SI 2010/1001 ('AQS Regulations') and related legislation in Scotland, Wales, Northern Ireland. See also nn 138-142 and accompanying text.

53 The Environmental Permitting (England and Wales) Regulations 2016 SI 2016/ 1154 ('EPRs').

54 The Greenhouse Gas Emissions Trading Scheme Regulations 2012 SI 2012/3038.

55 Environmental Protection Act 1990, pt 2; Waste (England and Wales) Regulations 2011 SI 2011/988 ('Waste Regulations'); and an array of fragmented legislative measures, see Fisher, Lange and Scotford (n 35) 552-4.

56 Wildlife and Countryside Act 1981; Countryside and Rights of Way Act 2000; Natural Environment and Rural Communities Act 2006; The Conservation of Habitats and Species Regulations 2017 SI 2017/1012, and related legislation in Scotland and Northern Ireland.

57 Climate Change Act 2008.

58 The Water Environment (Water Framework Directive) (England and Wales) Regulations 2017 SI 2017/407 ('WFD Regulations'), and related legislation in Scotland and Northern Ireland; and a wide range of legislative measures regulating the water industry and specific water sources, see Fisher, Lange and Scotford (n 35) 15.

59 Town and Country Planning Act 1990 (and related legislation in the UK devolved administrations); Planning Act 2008.

${ }^{60}$ There is a tsunami of EIA-related regulation in the UK, with obligations stemming from the EU EIA Directive (Directive 2011/92 on the assessment of the effects of certain public and private projects on the environment [2012] OJ L26/1) implemented through a wide range of UK secondary legislation, eg The Town and Country Planning 
regulation of chemicals, ${ }^{61}$ environmental sanctions, ${ }^{62}$ protecting landscapes, ${ }^{63}$ marine environment protection, ${ }^{64}$ regulation of genetically modified organisms (GMOs), ${ }^{65}$ and more. Legislation is required to give the state a role, and all of us a stake, in these issues that affect the natural environment, our built environment, and our health and wellbeing.

So collective, complex, dynamic environmental issues inherently lend themselves to concerted action through legislative measures. Moreover, legislation can be particularly important in the area of environmental law. It is highly symbolic. It sets out state-sponsored commitments to sets of rules and regulatory priorities in areas of environmental policy, to citizens, businesses, and even other countries. ${ }^{66}$ It also plays an important role in delimiting as well as constructing administrative structures within the state to address environmental issues through regulatory activity ${ }^{67}$ - extensive state power governing environmental issues is subject to law through legislative definition of that power.

As indicated above, legislative processes are also important for addressing the kinds of socio-political conflict inherent in developing responses to many environmental problems. Climate change is a prime example where the desired policy goals over recent decades have been contentious, and the means of achieving those policy goals (after further legislative change in $2019,{ }^{68}$ the UK has a legislative commitment to reducing GHG emissions by $100 \%$ against 1990 levels by 2050) remain so. The UK Climate Change Act 2008 is important not just for its strong external signal that climate change is a core concern of the UK government, but because the legislative process behind its creation allowed views to be aired and debated in Parliament on this fraught issue of social and economic policy. Its enactment then formally resolved any disagreement that climate change was a pressing policy problem that required long-term transformational social and economic

(Environmental Impact Assessment) (England and Wales) Regulations 1999 SI 1999/ 23.

${ }_{62}$ Eg The REACH Enforcement Regulations 2008 SI 2008/2852.

62 Regulatory Enforcement and Sanctions Act 2008.

63 Countryside and Rights of Way Act 2000 pt IV.

${ }^{64}$ Marine and Coastal Access Act 2009.

${ }^{65}$ Eg The Genetically Modified Organisms (Contained Use) Regulations 1992 SI 1992/3127; The Genetically Modified Organisms (Deliberate Release) Regulations 1992 SI 1992/3280; and related legislation in the UK devolved administrations.

${ }^{66} \mathrm{~N}$ Zeegers, WJ Witteveen and B van Klink (eds), Social and Symbolic Efforts of Legislation under the Rule of Law (Edwin Mellen Press 2005).

${ }^{87}$ E Fisher, Risk Regulation and Administrative Constitutionalism (Hart 2007).

${ }^{68}$ The Climate Change Act 2008 (2050 Target Amendment) Order 2019 SI 2019/ 1056 ('Net Zero Order'). 
change. It also established an institutional architecture (through 5-yearly cycles of carbon budgeting and the Committee on Climate Change's role in particular) that structures ongoing policy debate about how to achieve our committed climate goals. For a polycentric problem like climate change that impacts on many sectors (and many areas of government), whether in addressing mitigation or adaptation, responding to this 'all of society' problem is a task particularly well suited to legislative assemblies and legislation. ${ }^{69}$

\section{Environmental Legislation: The Challenge of Evaluating It}

The nature of environmental problems thus makes a strong case for having environmental legislation, and we indeed have lots of it. But what makes environmental legislation a fraught topic for evaluation and scholarly research? This question matters because, without robust methods for examining environmental legislation (and an inclination to undertake this kind of work), there is a lot at stake, both in thinking about the integrity of our lawmaking system and law more generally, and in terms of environmental protection. This section first examines key features of environmental legislation that make it uncharted territory for legal analysis, and then analyses the UK environmental law statute book in two episodes: the complex statute book that had developed up until the major law reform phase required for the UK to leave the European Union; and the large exercise of statutory reform in UK environmental law to facilitate Brexit. Both these episodes highlight the legal variety and complexity of environmental legislation and the problems created by legislating for environmental protection under the 'stress of circumstances'.

\section{A. The Uncharted Features of Environmental Legislation}

Environmental legislation is an unruly legal landscape. Legislative change happens at a speed and scale that is demanding, if not impossible, to keep on top of-just seeing the legislative landscape accurately can be hugely difficult. In addition, novel legal concepts are

${ }^{69}$ E Scotford and S Minas, 'Probing the Hidden Depths of Climate Law: Analysing National Climate Change Legislation' (2019) 28(1) Review of International and Comparative Environmental Law 67. 
introduced in legislation, with no pre-existing frames of analysisthese include new forms of property such as ETS (emission trading scheme) allowances, ${ }^{70}$ or a duty of care in waste regulation that is unrelated to tort law duties of care, ${ }^{71}$ or duties on Ministers to establish plans for achieving environmental outcomes in 'within the shortest possible time' ${ }^{72}$ There is no pre-defined methodology for categorizing or researching these creations of environmental legislation. ${ }^{73}$ This matters because we need ways of conceptualizing these legal notions and obligations, of knowing whether they are useful or not and if they are well designed for their purposes. They are no less significant to consider as legal norms because they are 'regulatory', which is the implication when legislative provisions remain relatively ignored by scholars and commentators until some illuminating case law comes along. There is also the significant challenge of 'legal interdisciplinarity $^{, 74}$ - understanding how new norms and forms of regulation for addressing environmental problems sit within the existing institutional, constitutional, and doctrinal legal structures that already exist, or which are co-evolving, such as doctrines of public law, property law, or tort law. ${ }^{75}$

Furthermore, environmental legislation is legally unusual in that it routinely expresses, dictates, or relies on policy. One might say that all legislation reflects policy choices but this is something distinctive. Some legislation requires environmental 'policy' to be taken into account in decision-making, giving rise to legal questions about what such legislatively framed 'policy' is. ${ }^{76}$ Furthermore, significant pieces

${ }^{70}$ Directive 2003/87/EC establishing a system for greenhouse gas emission allowance trading within the Union [2003] OJ L275/32. See S Bogojevic, Emissions Trading Schemes: States, Markets and Law (Hart Publishing 2013).

${ }^{71}$ Environmental Protection Act 1990, s 34.

${ }^{72}$ AQS Regulations (n 52) reg 26(2).

73 As Liz Fisher, Cinnamon Carlarne, Bettina Lange and I put it in a 2009 article, 'Environmental law as an object of scholarship and research does not yield easily to a single paradigm, methodology or explanation': E Fisher, B Lange, E Scotford, C Carlarne, 'Maturity and Methodology: Starting a Debate about Environmental Law Scholarship' (2009) 21(2) Journal of Environmental Law 213-250, 225.

${ }^{74}$ ibid 230.

75 Eg E Scotford and R Walsh, 'The Symbiosis of Property and English Environmental Law - Property Rights in a Public Law Context' (2013) 76(6) Modern Law Review 1010.

${ }^{76} R$ (Friends of the Earth Ltd and others) $v$ Heathrow Airport Ltd [2020] UKSC 52 (overturning the Court of Appeal on this point: Plan B Earth $v$ Secretary of State for Transport [2020] EWCA Civ 214). See J Bell and E Fisher, "The "Heathrow" Case: Polycentricity, Legislation, and the Standard of Review' (2020) 83(5) MLR 1072. 
of environmental legislation are 'policy-like' in that they expressly goal oriented $^{77}$ - establishing outcomes of result to be achieved (by government) rather than standards of individual conduct. ${ }^{78}$ Thus some statutes require: that government achieves prescribed levels of air and water quality within a certain timeframe; ${ }^{79}$ that we achieve net zero GHG emissions by $2050 ;{ }^{80}$ that government must draw up strategic plans and programmes for waste prevention and recovery, for air quality, and so on, according to specific criteria and goals. ${ }^{81}$ This approach to lawmaking is not just at odds with some prominent legal philosophical accounts of what law is, ${ }^{82}$ it also has constitutional ramifications. Legislation prescribing strict environmental policy outcomes sets constraints on policymaking across wide spheres of economic and social life that might be thought the discretionary domain of government policymaking. Thus, for example, legal obligations to achieve air quality standards require concerted, coordinated action to be taken in a wide range of government policy areas, from transport and industry, to town planning and environmental monitoring, as well as through individual behaviour (it is no wonder that achieving these standards has been so elusive). ${ }^{83}$ These kinds of statutory duties and obligations set up policy tensions with the way that the UK government has conventionally operated-both in its structure and with its perceived policy prerogative. A related legislative phenomenon, with constitutional implications, is seen where high-level government policymaking is subject to strategic environmental assessment. ${ }^{84}$ Again, government policy

77 Westerman identifies this as a new kind of legal norm: P Westerman, 'The Emergence of New Types of Norms' in LJ Wintgens (ed), Legislation in Context: Essays in Legisprudence (Ashgate 2007) 117.

78 This is an extreme form of Rubin's characterisation of legislation in the administration state as 'a set of public policy directives that the legislature issues to government implementation mechanisms': Rubin (n 27) 374. On the difficulties of construing these kinds of legal obligations, see C Reid, 'A New Sort of Duty? The Significance of "Outcome” Duties in the Climate Change and Child Poverty Acts' [2012] 4 Public Law 749.

79 AQS Regulations (n 52) reg 17; WFD Regulations (n 59) reg 3.

${ }^{80}$ Net Zero Order (n 68).

${ }^{81}$ Eg Waste Regulations (n 55) reg 4.

82 cf prominent theories of law that understand law primarily as norms that regulate human conduct, most famously HLA Hart, The Concept of Law (2nd edn, OUP 1997).

${ }^{83} R$ (ClientEarth (No 3)) $v$ Secretary of State for Environment, Food and Rural Affairs and ors [2018] EWHC 315 (Admin).

84 The Environmental Assessment of Plans and Programmes Regulations 2004 SI 2004/1633 (and similar legislation in the devolved administrations); E Scotford, 'The SEA Directive and the Legal Construction and Control of Government Environmental Policy' in E Scotford and G Jones (eds), The Strategic Environmental Assessment Directive: A Plan for Success? (Hart Publishing 2017). 
discretion is legally limited by legislative provisions that do not carry the jurisprudential weight of 'rights' and which are not framed in any quasi-constitutional form (in fact these policy limitations are contained in secondary legislation, transposed originally from EU law). ${ }^{85}$

In the common law tradition, policy ideas like environmental protection goals are generally divorced from legal reasoning and legal analysis. ${ }^{86}$ A similar reluctance to embrace policy goals on the face of legislation affects the tradition of UK legislative drafting, ${ }^{87}$ with high level policy goals being more appropriate for political debate and governmental discretion. ${ }^{88}$ Thus when policy goals become legally mandated or legal norms become mandated through policy-as happens in some environmental legislation-lawyers find themselves in uncomfortable theoretical, doctrinal, and methodological territory. ${ }^{89}$

All of these legally uncharted features of environmental legislation are rife in the UK statute book, and exacerbated by the drafting techniques, frequent amendment, and sheer density of UK environmental legislation. These features require repeated acts of 'legal imagination' on the part of lawyers - practising and scholarly alike - to construe these developments, weave them into the legal order, and develop our corpus of environmental law. ${ }^{90}$ The following sub-sections explore this

${ }^{85}$ Another related, distinctive feature of much environmental legislation is that it often relies on policy documents to supplement regimes it establishes. This is not uncommon in other areas of social and economic regulation, but the technical complexity and operational requirements of much environmental legislation mean that some policy documents contain, or effectively contain, primary norms of conduct binding operators or others subject to an environmental regime. Eg statutory guidance for the contaminated land regime issued under Environmental Protection Act 1990, s 78YA: DEFRA, Environmental Protection Act 1990: Part $2 A$ - Contaminated Land Statutory Guidance (April 2012).

${ }_{87}$ R Dworkin, Taking Rights Seriously (2nd edn, Duckworth 1978) 22-28, 84.

${ }^{87}$ See section 4(C) below on the convoluted and contested approach to incorporating environmental policy principles into UK legislation. However, under EU law, this tendency of introducing 'goal-legislation' became widespread in UK law through the transposition of EU Directives, imposing cascading obligations of result, or 'outcome-based regulation', through a system of legalised multi-level governance: P Westerman, Outsourcing the Law: A Philosophical Perspective on Regulation (Edward Elgar 2018); P Westerman, 'Breaking the Circle: Goal-Legislation and the Need for Empirical Research' (2015) 1(3) The Theory and Practice of Legislation 395.

${ }^{88} R v$ Secretary of State for the Environment; ex $p$ Hammersmith and Fulham LBC [1991] UKHL 3, 12.

${ }^{89}$ See Cormacain (n 34) 123 (acknowledging the 'difficulty' posed by legislation that 'doesn't actually contain any law', and referencing various ways in which legal scholars have sought to dismiss as law legislation that 'doesn't actually do something' in terms of imposing justiciable rights and obligations).

${ }^{9}$ Fisher, 'Legal Imagination' (n 31). 
empirical reality through an historical narrative, demonstrating the contours of this body of law in two episodes: pre- and post-Brexit.

\section{B. The Pre-2019 UK Environmental Statute-Book}

The landscape of modern UK environmental legislation is over 40 years in the making, located in a wide array of statutes, which have been repeatedly reformed, supplemented, updated. Frequent amendment-done usually by means of 'legislative microsurgery' rather than fresh legislation ${ }^{91}$ - is to be expected in the field of environmental law as environmental problems, and our knowledge and priorities concerning them, continually evolve. Environmental legislation is also highly fragmented-with legislative power in the environmental field devolved to the four nations of the UK adding a considerable layer of complexity in this respect. ${ }^{92}$ Even general environmental statutes read as miscellaneous lists of provisions relating to different environmental policy areas (waste, air quality, contaminated land etc), and over time are hollowed out with extensive deletions and subsequent amendments, which are not consolidated. The Environmental Protection Act 1990 is not easy reading, and accessing it online might not be accurate reading. ${ }^{93}$

Environmental legislation also relies heavily on secondary legislation, supporting guidance, Ministerial directions, and various obscure drafting techniques for incorporating the extensive body of EU environmental law, ${ }^{94}$ which, until 31 December 2020, was applicable in the UK. The EU has competence, on the basis of subsidiarity, in a wide range of environmental policy matters, ${ }^{95}$ and has used this competence to legislate extensively since the 1970s. Transposing this EU environmental legislation into UK law over time led to an extensive reliance on secondary legislation in UK law in establishing environmental regimes. For example, the entire English permitting regime is contained in secondary legislation (a virtuoso example of legislative

${ }^{91}$ Beatson (n 17) 301.

92 Scotland Act 1988, s 29; Northern Ireland Act 1988, s 6; Government Wales Act 2006, s 108.

${ }^{93}$ E Scotford and J Robinson, 'UK Environmental Legislation and its Administration in 2013: Achievement, Challenges and Prospects' (2013) 25(3) Journal of Environmental Law 383.

${ }_{94}$ UKELA, King's College London and BRASS, The State of UK Environmental Legislation in 2011-2012: Is There a Case for Legislative Reform? (Interim Report, August) $76-105$.

93 TFEU, Title XX. 
drafting) $;{ }^{96}$ the main water pollution offence is in secondary legislation; ${ }^{97}$ the habitats protection and EIA regimes are contained in secondary legislation, ${ }^{98}$ woven then into the planning system, also constructed by legislation. ${ }^{99}$

From a rule of law perspective, it is deeply problematic that primary obligations of conduct are contained in secondary legislation. ${ }^{100}$ This undermines the transparency and public 'knowability' of legal obligations, and it also makes the process by which secondary legislation is created particularly important. When advocating the rule of law virtues of legislation, Waldron explains the importance of 'legislative due process' as involving: ${ }^{101}$

Bicameralism, checks and balances (such as executive veto), the production of a text as the focus of deliberation, clause-by-clause consideration, the formality and solemnity of the treatment of bills in the chamber, the publicity of legislative debates, successive layers of deliberation, and the sheer time for consideration-formal and informal, internal and external to the legislature-that is allowed to pass between the initiation and the final enactment of a bill.

Secondary legislation does not get this kind of due process, particularly when subject to the negative resolution procedure in Parliament, but it can have wide-ranging regulatory impacts. Environmental law is not the only area of law that is a casualty of bypassed parliamentary process, ${ }^{102}$ and the UK statute book is generally compromised by 'legislative hyperactivity', as Lord Bingham has described it in criticizing the accessibility of UK legislation. ${ }^{103}$ But environmental law is a subject particularly suited to legislation, and where the EU has legislated widely, leading to extensive transposition of environmental law by secondary legislation through a system of delegated lawmaking that is not

${ }^{96}$ EPRs (n 53).

97 ibid, reg 38.

98 The Conservation of Habitats and Species Regulations 2017 SI 2017/1012, and related legislation in Scotland and Northern Ireland. On EIA legislation, see n 55.

99 (n 59).

100 J King, 'The Province of Delegated Legislation' in E Fisher, J King, and A Young, The Foundations and Future of Public Law: Essays in Honour of Paul Craig (OUP 2020).

${ }^{101}$ Waldron, 'Legislation and the Rule of Law' (n 26) 107.

102 Beatson (n 17).

${ }^{103}$ Lord Bingham, 'The Rule of Law' (2007) 66(1) CLJ 67, 70 ('the legislative hyperactivity which appears to have become a permanent feature of our governance', causing 'serious problems of accessibility, despite the internet. And this is compounded by the British tradition of parliamentary draftsmanship which, for all its technical virtuosity, depends so heavily on cross-reference and incorporation as on occasion to baffle'). 
transparent or reliability rigorous in its scrutiny processes. ${ }^{104}$ This means environmental law is a subject particularly beset by these kinds of rule of law issues.

Thus, the statute book for environmental law is messy, fragmented, not easily intelligible, and not as well made as it might be-less ugly modern highway; more unplanned urban sprawl. This has at least three consequences. One is that environmental lawyers need to be really good lawyers. For many environmental law practitioners and professionals, this legislative complex is their 'material', ${ }^{105}$ the law that they work with and that they know. They are expert in knowing and applying it. Second, more worryingly, legislative complexity and obscurity might undermine environmental protection. Eric Orts, observing a similar situation in US environmental legislation, described expanding, unwieldy environmental legislation as 'environmental juridification', or as others had less politely called it, 'legal pollution', which has troubling consequences: ${ }^{106}$

The sheer amount environmental law threatens to clog the wheels of society as a whole... When a body of law becomes so complex and arcane that it cannot even be known, let alone fully complied with or enforced, one cannot hope that its objectives will be realized.

The third consequence is that the integrity of the law is compromised. This picture of law is compromised on at least the grounds of publicity, practicability, consistency, intelligibility-four of the eight principles that, on Lon Fuller's account, comprise the inner morality of the law (assuming legislation counts as law). ${ }^{107}$ This view was supported by empirical findings of a project undertaken by the UK Environmental Law Association in 2011-12. ${ }^{108}$ This project analysed the coherence, transparency, and workability of UK environmental

104 Statutory Instruments Act 1946. See J Simson Caird and E Patterson, 'Brexit, Delegated Powers and Delegated Legislation: A Rule of Law Analysis of Parliamentary Scrutiny' (Bingham Centre for the Rule of Law $2020<$ https://binghamcentre.biicl.org/ publications/brexit-delegated-powers-and-delegated-legislation-a-rule-of-law-analysisof-parliamentary-scrutiny $>$ accessed 28 September 2021.

105 E Fisher, 'Back to Basics: Thinking About the Craft of Environmental Law Scholarship' in O Pedersen (ed), Perspectives on Environmental Law Scholarship: Essays on Purpose, Shape and Discretion (CUP 2018).

106 E Orts, 'A Reflexive Model of Environmental Regulation' (1995) 5(4) Business Ethics Quarterly 779, 782.

${ }_{107}$ L Fuller, The Morality of Law (Yale University Press 1964).

108 UKELA, King's College London and BRASS, The State of UK Environmental Legislation in 2011-2012: Is There a Case for Legislative Reform?, May 2012 (Final Report) (I coordinated this project with UKELA partners, and co-authored this report with Rosie Oliver). 
legislation, including through interviewing environmental law professionals, jurists, academics, and businesses subject to environmental laws. It found that UK environmental legislation is too complex and lacks clarity, that various legislative practices adversely affect the coherence and transparency of environmental legislation (such as referential drafting, frequent amendment without consolidation, and use of Ministerial directions), and that the overall legislative picture is poorly integrated (substantively and administratively). ${ }^{109}$ The report also found that the overreliance on secondary legislation makes environmental legislation particularly vulnerable to weaker oversight processes in its creation. ${ }^{110}$ To remedy these legal flaws, the report made initial recommendations for change-concerning consolidating legislation, the appropriate use of guidance, reviewing particularly troublesome provisions, exploring clunky intersections between different legislative regimes, and on improving legislative scrutiny practices. ${ }^{111}$ In making these recommendations, that project unearthed a legislative timebomb that subsequently exploded with Brexit.

\section{The Brexit Environmental Legislation Explosion}

The UK's departure from the European Union, formally on 31 January 2020, led to a further, time-pressured episode of legislative hyperactivity in UK environmental law. This involved rewriting an extensive body of EU-derived UK legislation to ensure that it remained valid law once the supporting structure of the European Communities Act 1972 was withdrawn. This hectic lawmaking episode augmented considerably the transparency, legibility and legitimacy problems with the existing statute book outlined in the previous sub-section.

Preparing the UK statute book for the UK's planned departure from the EU was an immense job for parliamentarians and government officials. Part of that workload was attempting to ensure that the UK's EU-derived environmental law (amongst all other EU-derived law) was properly 'retained' as the UK left the EU, to facilitate a 'calm and orderly' Brexit. $^{112}$ Environmental policy was the area of UK

109 ibid 7-12.

110 ibid 12.

111 ibid 13-16.

112 The Secretary of State for Exiting the European Union, UK Parliament, 'Next Steps in Leaving the European Union' (HC Deb of 10 October 2016, vol 615, col 40) $<$ https://hansard.parliament.uk/Commons/2016-10-10/debates/6CE5F6BB-3AA44332-BF7A-577DB35BDB77/NextStepsInLeavingTheEuropeanUnion\#contribution1F98EB16-0F24-401D-AA92-C0D4DCDE2BB3> accessed 28 September 2021. 
government most affected by this task. The Department of Environment, Food and Rural Affairs (DEFRA) had more legislation to 'Brexit-proof than any other government department, being responsible for around $25 \%$ of all, or around 100 , statutory instruments ('SI's) introduced under the European Union (Withdrawal) Act 2018's controversial powers to amend EU law to eliminate any 'deficiencies' in the law on EU exit day. ${ }^{13}$ This work in retaining EU environmental law was partly an exercise of detailed rewriting of many specific legislative provisions-done through new secondary legislation (with less scrutiny, at speed and at scale) - to ensure it 'made sense' without the rest of EU law and EU institutions to refer to or rely on. Furthermore, this exercise in SI amendment of our statute book was, despite the official characterization, far from technical. Emily Lydgate and colleagues have shown, in the context of food safety legislation, that this is because SI amendments are establishing a new set of domestic institutional 'capacities, competencies and procedures' for regulating environmental issues (such as GMO authorization), and also creating Ministerial powers to further amend regulation in the future. ${ }^{114}$

Beyond legislative complexity created by this vast redrafting exercise, which was aimed primarily at keeping environmental law static as the UK left the EU, there were other 'legal gaps', ${ }^{115}$ and indeed legal opportunities, which opened up in the huge legal transition of Brexit. In terms of legal gaps, there are aspects of EU environmental law that applied in UK law when it was bound by EU law, but which sat beyond the UK legislation directly transposing EU environmental law. These included EU institutional structures and governance frameworks, including the impactful infraction powers of the EU Commission, ${ }^{116}$ and the environmental principles located in the EU Treaties (such as the precautionary principle and polluter pays

113 Select Committee on the Constitution, European Union (Withdrawal) Bill: Interim Report (HL 2017-19, 19); P Craig, 'Constitutional Principle, the Rule of Law and Political Reality: the European Union (Withdrawal) Act 2018' (2019) 82(2) Modern Law Review 319.

114 E Lydgate and others, 'Briefing Paper: Brexit Food Safety Legislation and Potential Implications for UK Trade: The Devil in the Details' (UK Trade Policy Observatory Briefing Paper 37, October 2019) < https://blogs.sussex.ac.uk/uktpo/publi cations/brexit-food-safety-legislation-and-potential-implications-for-uk-trade-the-devilin-the-details/> accessed 28 September 2021.

${ }^{115}$ M Lee, 'Brexit and environmental protection in the United Kingdom: governance, accountability and law making' (2018) 36(3) Journal of Energy and Natural Resources Law 351.

${ }_{116}$ DEFRA, Draft Environment (Principles and Governance) Bill Statement of Impacts (December 2018) 2-3. 
principle). ${ }^{117}$ These environmental principles are a legal archetype of crystallising environmental policy in legal form, with constitutionalised roles in the EU treaties, and they have played fundamental roles in shaping EU and thus UK environmental law over the last 40 years. ${ }^{118}$

These 'legal gaps', such as losing the higher normative status of environmental principles though Brexit, prompted much consternation amongst UK politicians and NGOs when the European Union (Withdrawal) Act 2018 was being negotiated. A commitment to ensuring that the full gamut of EU environmental law was brought across into UK law on EU exit was seen as critical to ensuring that environmental standards would not fall in the UK after Brexit. ${ }^{119}$ The perceived guarantee to guard against this policy dilution risk was legislation, with legalizing policy goals through legislation as part of the answer. Environmental principles introduced in UK legislation were seen as fundamental legal guarantees in this respect. Indeed, in all jurisdictional settings where environmental principles have a legal role, the symbolic value of environmental principles in entrenching a longterm, ambitious vision for environmental law and policy is a prominent feature. ${ }^{120}$ And the stronger the legal prescription of principles, the more embedded are their legal effects. ${ }^{121}$ However, in this particularly fraught legislative exercise, designing environmental principles as fundamental features of UK (rather than EU) legislation was not easy, drawing UK environmental legislation yet again into unchartered 'policy' waters.

Beginning in 2018, a tortured process of creating new UK environmental legislation to fill EU governance gaps unfolded. This resulted in the UK/English Environment Bill 2019-21, and what is now the related UK Withdrawal from the European Union (Continuity) (Scotland) Act 2021. ${ }^{122}$ During the political and legislative processes for creating these statutes, ${ }^{123}$ there were intense debates over how EU environmental

117 TFEU, arts 11 and 191(2).

118 E Scotford, Environmental Principles and the Evolution of Environmental Law (Hart 2017) ch 4.

119 Greener UK, 'The Governance Gap: Why Brexit Could Weaken Environmental Protections' (Briefing for Parliamentarians and Policymakers, August 2017).

${ }^{120}$ E Scotford, 'Environmental Principles Across Jurisdictions: Legal Connectors and Catalysts' in E Lees and J Vinuales (eds), Oxford Handbook of Comparative Environmental Law (OUP 2019).

${ }^{121}$ As seen in EU law: see Scotford, Environmental Principles and the Evolution of Environmental Law (n 118) ch 4.

${ }_{122}$ At the time of writing, related legislation was still anticipated in Wales.

123 For the UK/English Environment Bill, its life began with s 16 European Union (Withdrawal) Act 2018, requiring draft legislation within 6 months containing, inter 
policy principles might be retained in a domestic statute; ${ }^{124}$ and related debates over whether ambitious environmental objectives should appear on the face of the Bill, ${ }^{125}$ and over how non-regression of environmental standards might be guaranteed in legislation. ${ }^{126}$ One view is that none of these things is appropriate for legislation, ${ }^{127}$ or that these things are legally impossible to craft (particularly in the case of non-regression in light of parliamentary sovereignty where a future parliament can always override the statutory will of the current parliament). ${ }^{128}$ However, if we accept that environmental legislation is properly concerned with promoting environmental goals, and that this cannot happen only by providing rules of conduct (such as through permitting regimes and environmental offences), this also requires some legal prescription and articulation of collective environmental policy goals. In the post-Brexit UK context, this imperative became a contentious and complex exercise in legislative drafting and enactment.

The UK/English Environment Bill did not only seek to introduce environmental principles, and fill key governance gaps after Brexit,

alia, a set of listed environmental principles. A draft Environmental (Principles and Governance) Bill 2018 followed, setting out provisions for English environmental governance and introducing certain environmental policy principles, and some provisions relating to UK reserved matters. That draft Bill was followed by a full government Environment Bill, introduced on the $15^{\text {th }}$ October 2019, which retained the draft Bill's provisions on principles and governance, amended in some respects after pre-legislative scrutiny, and added major sections on air quality, nature conservation, water law, and waste regulation. That Bill fell with a general election in December 2019, and was reintroduced with minor changes in January 2020. As at 28 September 2021, the Bill was awaiting its third reading in the House of Lords and significant amendments were causing disagreement between both Houses of Parliament on finalizing the Bill. The Bill had been due to receive Royal Assent by the end of 2021 but this timetable may yet be further extended.

${ }^{124}$ House of Commons Environmental Audit Committee, 'Scrutiny of the Draft Environment (Principles and Governance) Bill' (18th Report, Session 2017-19, 24 April 2019) ('EAC Report') <https://www.parliament.uk/business/committees/commit tees-a-z/commons-select/environmental-audit-committee/inquiries/parliament-2017/ copy-this-page-inquiry-name-17-191/> accessed 28 September 2021; M Lee and E Scotford, 'Environmental Principles After Brexit: The Draft Environment (Principles and Governance) Bill' (2019) Working Paper <https://papers.ssrn.com/sol3/papers. cfm?abstract_id=3322341> accessed 28 September 2021.

125 Broadway Initiative, 'The Environment Bill - Seizing the Opportunity' (February 2020).

${ }^{126}$ Greener UK, 'Briefing on Non-regression in the Environment Bill' (4 October 2018); EAC Report (n 124) 50-51.

${ }^{127}$ D Feldman, 'Legislation as Aspiration: Statutory Expression of Policy Goals' (Lecture for the Statute Law Society, 16 March 2015).

${ }^{128}$ See Environment Bill, cl 21 for a novel effort to implement non-regression, which is more an alert system for Ministers to warn Parliament that regressive legislation may be implemented, against an artificial benchmark of currently applicable legal standards of environmental protection. 
including creating a new enforcement machinery for English environmental law. It was the first major piece of primary UK environmental legislation in two decades, with major sections reforming law on air quality, water quality, waste and nature conservation. The government introduced the Bill as an opportunity for world-leading environmental law reform. ${ }^{129}$ It is however a curiously, and worryingly, drafted piece of legislation. It puts unusual amounts of power in the executive throughout ('executive environmental law' as Liz Fisher explains it), ${ }^{130}$ raising concerns about the constitutional propriety of this post-Brexit legislation. It also introduces environmental standard-setting powers that may allow weaker environmental standards to be introduced in the future. ${ }^{131}$ Its new enforcement regime turns on a definition of 'failing to comply with environmental law' that baffles-the existence of an explicit definition suggests that the conduct covered is either wider or narrower than the literal meaning of this phrase. ${ }^{132}$ Its compliance mechanism ultimately relies on principles of judicial review for enforcing breaches of environmental law, ${ }^{133}$ which conflates the purposes of administrative law (good public administration) and regulatory enforcement (good regulatory outcomes). On environmental principles, the Bill delegates the policy-mandating function of these principles to a prescriptive policy statement, drafted by the Minister, which is subject to weak parliamentary scrutiny. ${ }^{134}$ It enshrines environmental principles in primary legislation as free-floating ideas that have no firm legal anchors or explicit connections to the rest of environmental law, including weak statutory links to the sections in the rest of the Bill.

The Bill's provisions are not known or solid, whether to lawyers, scholars, or the public. They construct a form of UK environmental legislation that is very hard to analyse. Three parliamentary committees

129 DEFRA, 'Government Introduced ground-breaking Environment Bill' (Press release, 15 October 2019) <https://www.gov.uk/government/news/government-introdu ces-ground-breaking-environment-bill $>$ accessed 24 August 2020.

${ }^{130}$ E Fisher, 'Executive Environmental Law' (2020) 83 Modern Law Review 163.

131 E Scotford, S Tromans and 23 UK academics and practitioners, 'Environment Bill: Joint Letter to the Editor' The Telegraph (30 October 2019) (expressing concern over claims that the Environment Bill 2019-20 maintains current environmental protections and enshrines the highest standards in law).

${ }^{132}$ Environment Bill, cl 32. One either complies with the law or one does not. cf $s$ 43 of the UK Withdrawal from the European Union (Continuity) (Scotland) Act 2021 ('Scottish Continuity Act'), also a strange provision but drafted differently, which appears widen the scope of potential breaches caught by the Scottish enforcement regime.

${ }^{133}$ Environment Bill, cl 39.

${ }^{134}$ Environment Bill, cl 18-20. 
directly investigated the partial draft Bill and the full Bill, ${ }^{135}$ and government consulted widely on whether and how the legislation would work. Academic debate and discussion were vibrant and highly engaged. ${ }^{136}$ In public and private discussions about this much debated legislation, the stress and consternation were palpable. This stress was driven by politics. As outlined above, there was a strong political mandate in government to deliver legislation that is 'legally equivalent' to existing EU environmental law, whilst a political drive to legislate to uphold high environmental standards was motivating NGOs, some MPs, and increasingly the public. At the same time, the UK has a legal and political culture in which prescribing policy (and constructing enforcement mechanisms against the government) in primary legislation is not the norm, and faces resistance. This problem of environmental politics created a huge legal and legislative challenge, which played out under considerable time pressure. This was very much Dicey's territory of legislation having being produced by the 'stress of circumstances'.

This Bill must also sit alongside the rest of the body of UK environmental legislation. It does not just add to a fragmented and complex legal landscape but multiplies it, in three different ways. First, the Bill's commencement provisions allow for staggered temporal enlivening of different parts of the Bill, and its geographical coverage is highly fragmented. ${ }^{137}$ Second, the Bill drives legal fragmentation aross the constituent elements of the UK. Related legislation in the devolved administrations looks set to diverge from the English Bill in key respects. This is already seen in the Scottish Continuity Act 2021,

135 The draft Bill was subject to pre-legislative scrutiny in 2019 by the Environmental Audit Committee (see n 124) and House of Commons Committee on Environment, Food and Rural Affairs; the full Bill was scrutinised by the Public Bill Committee in 2020. In addition, other parliamentary committees scrutinised the Bill indirectly, such as the House of Commons Committee on Environment, Food and Rural Affairs Inquiry on Air Quality in 2020.

${ }^{136}$ Eg C Burns, 'Will Brexit Degrade UK Environmental Policy?’ (2020) 119 (815) Current History 101; Fisher (n 130); V Gravey, M Dobbs and C Brennan, 'Out of the Frying Pan, Into the Fire? Environmental Governance Vulnerabilities in Post-Brexit Northern Ireland' (2019) 21(2) Env LR 84; M Lee, 'The Environment Bill: A Framework for Progressive Environmental Law?' (Brexit\& Environment blog, 18 October 2019); R Macrory; Irresolute Clay: Shaping the Foundations of Modern Environmental Law (Hart 2020) ch 13; C Reid, 'The Future of Environmental Governance in the (Dis-) United Kingdom' in A Biondi, PJ Birkinshaw, and L Kendrick (eds) Brexit: The Legal Implications (Wolters Kluwer 2018).

137 Environment Bill, $\mathrm{cl} 149$ and 150 (the mixed geographical extent of the Bill is partly due to UK reserved powers but also to agreements with the devolved administrations over specific matters). For the preexisting fragmentation of UK environmental legislation, see Scotford and Robinson (n 92). 
which contains firmer statutory commitments to environmental protection goals and environmental enforcement. ${ }^{138}$ Third, the Bill must also sit alongside retained EU law, and the pre-existing body of UK environmental legislation. Pre- and post-Brexit environmental law thus create a further axis of legal fragmentation. Making sense of this complex statutory landscape is a tall order, since these different bodies of UK environmental legislation have not been designed to co-exist neatly.

Take, as an example, the air quality standards that have become symbolic and important benchmarks for clean air across the EU. ${ }^{139}$ In English law, post-EU exit, to know what air quality standards are, one must look first to the Air Quality Standards Regulations 2010, ${ }^{140}$ which implemented EU law standards, but as these are amended by The Air Quality (Amendment of Domestic Regulations) (EU Exit) Regulations 2019. ${ }^{141}$ One must also look at similar but not equivalent air quality standards and objectives in the national Air Quality Strategy, introduced under the Environment Act 1995. Then it is necessary to look at the UK/English Environment Bill, which contains further provisions for setting air quality standards on a different model of standard setting (long term, capable of being achieved, subject to being lowered), under which at least two new air quality standards must be introduced, again in secondary legislation. ${ }^{142}$ If the legal obligations relating to any of these standards are required to be interpreted in court, they will be subject to different schemes of legal interpretation (since some are retained EU law and some are new English law), thanks to the provisions of the European Union (Withdrawal) Act 2018 on the interpretation of retained EU law. ${ }^{143}$ This interpretive statute is potentially further complicated by the troublesome section

${ }^{138}$ Eg Scottish Continuity Act (n 132) imposes more direct duties on Scottish government and public actors to have regard to environmental principles, and establishes more direct sanctions on government for failing to comply with environmental law (in some cases at least). It also contains powers to implement new EU environmental law from time to time ('keeping pace' provisions). This divergence in Scottish law creates potential regulatory tensions for the UK internal market, particularly in light of the market access principles in the UK Internal Market Act 2020, creating another sphere of legislative and political complexity for UK environmental law. See C Burns and N Carter, 'Brexit and UK Environmental Policy and Politics' (2018) 23(3) Revue Française de Civilisation Britannique 1.

${ }_{139}$ Directive 2008/50 on ambient air quality and cleaner air for Europe [2008] OJ L152/1.

${ }^{140}$ (n 52).

141 SI 2019/74.

142 Environment Bill, cl 1-8.

143 European Union (Withdrawal) Act 2018, s 6. 
26 of the European Union (Withdrawal Agreement) Act 2020, giving Ministers power to issue delegated legislation dictating which courts and tribunals should be able to depart from CJEU judgments. And this is only to discern English standards; a different set of air quality standards may continue to emerge in the legislation of the UK's devolved administrations, assuming they retain environmental policymaking discretion in this respect. This legislative picture-of knowing what is a basic UK environmental standard and understanding related legal obligations - is overwhelming for a legal practitioner or academic, not to mention being the wickedest problem question you might set for a law student. Knowing what our environmental law is became much harder after Brexit, and this kind of legislative picture is alarming for legal clarity, for transparency, and for the rule of law.

The answer to this highly unsatisfactory state of affairs is not to reject legislation as a form of law, or to retreat to conventional forms of legislative drafting that fail to grasp the legal complexities of our EU/UK recent legal history, or to compromise our committed social goals of environmental protection, or to get something down in legislation and hope for the best in our bright political future. Robust and subtle legal analysis was and remains critically important at this huge moment for environmental legislation, ${ }^{144}$ and it is what academics and legal practitioners are trained to do. We need to craft new frames of reference where appropriate, ${ }^{145}$ dissect the detail, ${ }^{146}$ and argue the case when legislation is flawed (on policy, analytical, or rule of law grounds). ${ }^{147}$ It is particularly the task of environmental law scholars to find new paths at the legislative frontier of the UK's unknown future environmental law. ${ }^{148}$

\section{Conclusion}

Under the stress of environmental problems and rapid political change, environmental legislation is under strain. We see our familiar frames of reference faltering, our scholarly tools straining, the political and environmental stakes escalating, our questions about the role—and rule—of

\footnotetext{
${ }^{144} \mathrm{C}$ Abbott and M Lee, Environmental Groups and Legal Expertise: Shaping the Brexit Process (UCL Press 2021).

${ }_{145}$ Lee and Scotford (n 124).

146 See eg UKELA's Brexit and Environmental Law series < https://www.ukela.org/ UKELA/ReadingRoom/Brexit/UKELAsworkonbrexit.aspx > accessed 24 August 2020".

${ }_{147}$ Fisher, 'Executive Environmental Law' (n 130).

${ }^{148}$ For pioneering efforts, see n 136.
} 
law proliferating. The environmental law community is often under time pressure to react to this state of affairs. Bad law being created is a distinct risk, with the attendant risk of seriously undermining environmental protection efforts.

One response to this is to bury one's head in the sand and reject legislation as a valid form of law. For environmental problems, that is not an option. Dicey's stressful circumstances are very real, particularly due to the key features of many environmental problems-socio-political and scientific complexity, dynamism, and the collective nature of these problems. The rationality of the common law does not fully address these kinds of social challenges, and leaving these issues unregulated is not a palatable option. We need to heed Dicey's warning about the risks of compromised legislation being made, but equally, legislative responses are needed for the state to address increasingly urgent and existential collective environment problems such as climate change, biodiversity loss and air pollution. This legal—and political— reality has however given rise to serious transparency, legibility and legitimacy problems with the existing UK statute book. These are only exacerbated by new legal approaches and layers of legal fragmentation ushered in by post-Brexit law reform. Much of the terrain of UK environmental legislation remains relatively uncharted territory for lawyers and legal scholars-from the legal character of legislative 'policy' and 'environmental principles' to the legal nature of environmental 'outcome' obligations. The challenge of mapping this law, and imagining its meaning and implications, is only intensifying in complexity and importance in the post-Brexit era.

The field of environmental law has sometimes been marginalized—in political and scholarly communities alike ${ }^{149}$ - and its contours are not easily defined or tested as an area for anlaysis and research. Times of stress are not just moments of risky lawmaking; they are also moments to galvanise scholarly and legal experience and ensure that difficult and pressing questions about environmental legislation, including new UK legislation that may shape our environmental law for decades to come, are asked (and asked again) and robustly investigated. When questions about the transparency, clarity, and constitutional propriety of new environmental legislation are arising, the intricate details of environmental legislation are not only deeply interesting but vital to explore.

149 On the scholarly marginalization of environmental law, see Fisher and others, 'Maturity and Methodology' (n 73). 